\title{
Stakeholder consultations on small-scale irrigation schemes' constraints in Zimbabwe
}

\author{
Edgar Muhoyi ${ }^{1}$ (D) . Josue Mbonigaba ${ }^{1}$
}

Received: 18 March 2020 / Accepted: 17 November 2021 / Published online: 4 December 2021

(C) The Author(s) 2021

\begin{abstract}
Small-scale irrigation schemes (SSIS) have been considered a solution to viability challenges in drought-stricken farming areas in developing countries. However, the schemes face severe constraints. In this paper, relevant constraints are identified and ranked in terms of how serious the limitations are from the perspective of stakeholders in droughtprone areas of the Chipinge District in Zimbabwe. Information for the study was gained through a questionnaire and focus group discussions with small-scale irrigation farmers as well as key informant interviews with government irrigation officials, irrigation managers and members of the local community leadership. The information was garnered between August and December in 2017 with the analysis conducted using descriptive statistics and thematic analysis, guided by the Theory of Constraints and classified in the political, economic, social, technological, environmental and legal (PESTEL) framework. Results indicated that SSIS are important in the drought-prone areas of the Chipinge District regarding food security and income generation. However, technical issues bedevilling the schemes are considered to be the most challenging limitations. The most important constraintsranked in descending order of gravity - are technical, economic, social, environmental, legal and political challenges. Based on these findings, the research strongly recommends modernising small-scale irrigation schemes' infrastructure, among other issues, as a priority in Zimbabwe's drought-prone areas.
\end{abstract}

Keywords Small-scale irrigation schemes $\cdot$ Constraints $\cdot$ Climate change $\cdot$ Drought-prone

\section{Introduction}

Climate change has become real, manifesting in various forms (Chikozho, 2010). It is predicted that wet areas of the world will become wetter, while dry areas may get drier (Gwimbi, 2009; IFPRI, 2006). This situation poses a daunting challenge for Africa's current and future development in drier areas where agricultural production occurs. In Africa, a significant proportion (70\%) of the population relies on rain-fed agriculture

Edgar Muhoyi

emuhoyi@gmail.com

1 School of Accounting, Economics and Finance, University of KwaZulu-Natal, Durban, South Africa 
with low inputs used for their livelihoods (IFPRI, 2006; Mertz et al., 2009; IPCC, 2013). The reliance on rain-fed agriculture is detrimental to the world's crops, which will need to feed a growing global population of about nine billion people by 2050 (Charles et al., 2010). The projected increase in population in Africa alongside prevailing climate change is likely to worsen food insecurity and poverty among rain-fed smallholder African farmers.

Zimbabwe is one of the most affected countries. Since the 1950s, the country has experienced extreme weather events, notably floods and severe droughts (Descheemaeker et al., 2018; Gwimbi, 2009; Kinsey et al., 1998; Makaudze \& Miranda, 2010; Makuvaro et al., 2018; Ncube et al., 2018). Nangombe (2014) notes, in particular, that droughts have become more recurrent and drastic than ever before. According to the study, extreme droughts were recorded in 1983 and 1992; severe droughts in 1968, 1973, 1982, 2004; and mild droughts in 1951, 1960, 1964, 1965, 1970, 1984, 1987, 1991, 1995, 2002, 2003, 2005 and 2007-2010. These occurrences have exposed many households to food and nutrition insecurity and worsened poverty levels in affected farming regions.

Furthermore, the effects of droughts have become a concern, given that $80 \%$ of the rural population in Zimbabwe are subsistence farmers who depend on rain-fed agriculture, which contributes between 15 and $18 \%$ to the Gross Domestic Product (GDP), provides about $60 \%$ of industrial raw material (Climate Smart Agriculture Manual for Zimbabwe, 2017) and accounts for $40 \%$ of national export earnings (Nyakudya \& Stroosnijder, 2011). The practice of rain-fed agriculture in the face of frequent droughts makes Zimbabwe's economy, particularly smallholder agriculture, highly vulnerable to climate change, thus supporting the argument of irrigation schemes being a relevant policy intervention.

Like other developing countries (Zawe, 2006; Hussain \& Hanjra, 2004), Zimbabwe has been pushing for SSIS establishments in drier regions (FAO, 2000) with efforts supported by national policies such as the Zimbabwe Policy Agenda for Sustainable Socio-Economic Transformation (2013) and the Transitional Stabilization Policy (2018). As a result, areas under irrigation have recently increased from 150000 ha to 220000 ha, with the 2018 Zimbabwe National Budget Statement allocating US\$52.1 million for irrigation activities.

The budget also sought to fund an additional 200 ha of irrigated land annually for the next ten years. Furthermore, development partners such as the International Fund for Agricultural Development (IFAD), OFID, FAO, EU, the Japan International Cooperation Agency (JICA), and the Swiss Agency for Development Cooperation, have supported SSIS initiatives in Zimbabwe (National Budget Statement, 2018; The, 2019 National Budget Statement, 2019). While these SSIS are meant to rescue small-scale farmers from climate change consequences, the schemes face sustainability challenges. Zimbabwe needs a minimum of 400000 ha of irrigated land to provide enough food for its needs but had only about 200000 ha under irrigation in 2017 (Climate Smart Agriculture Manual for Zimbabwe, 2017). This provides evidence of the small-scale irrigation sector being highly underdeveloped. Furthermore, the statistics from the Zimbabwe Vulnerability Assessment Committee (ZIMVAC) Reports (2012, 2013, 2014, 2016 and 2017) paint a gloomy picture of small-scale irrigation developments. The reports show the following in terms of existing smallholder irrigation schemes being dysfunctional-in 2012, about $62 \%$ were dysfunctional, in 2013 the figure was around 60\%, in 2014 56\%, in $201647 \%$ and in $201744,6 \%$. These statistics indicate a legacy of unsustainability in most smallholder irrigation schemes in the country. While this is a worrying situation, the constraints on SSIS, especially in Zimbabwe's drought-prone areas, are not well known even though they may limit SSIS farmers from realising the full potential of the above-mentioned irrigation developments. Therefore, research investigating constraints faced by SSIS, particularly in perennial dry 
areas, is pertinent as it would inform policymakers on how to deal with the constraints on and benefits from the irrigation schemes, which is the aim of this paper.

\section{Literature review}

The literature on SSIS constraints has been diverse and conducted in various periods and contexts (Table 1). Almost all studies sought solutions to the lingering issues in SSIS, intending to derive maximum benefit from the schemes. Most studies investigated the constraints faced by SSIS in Africa's developing countries and were conducted, for example, in Ethiopia (Mengistie \& Kidane, 2016; Aberra, 2004; Ayele, 2011), Ghana (Dinye, 2013; Adam et al., 2016), Swaziland (Nkambule and Dhlamini, 2013), South Africa (Magingxa et al., 2006; Fanadzo, 2012), Zimbabwe (Mutambara et al., 2016; Mutambara and Munodawafa, 2014; Manzungu, 1995) and Nigeria (Oriola, 2009). Other studies evaluated constraints at the regional level, including the European Union (Levidow et al., 2014), SubSaharan Africa (Bjornlund et al., 2016) and Southern Africa (Mutiro \& Lautze, 2015). Studies at a regional or country level evaluated policy and documentary evidence (Mutiro \& Lautze, 2015), while others used a mixture of documentary reviews and expert opinions on factors affecting SSIS (Silva et al., 2014). Their approaches were in contrast to research (Hallensleben, 2012; Mutambara et al., 2016; Mengistie \& Kidane, 2016, Mdemu et al., 2016, Moyo et al., 2016; Chibisa et al., 2008) focusing on case studies with an in-depth inquiry into operational issues. The non-exhaustive listing of factors identified in these studies includes the uncertainty of tenure, the inappropriateness of farm characteristics, poor-quality seed, insufficient fertiliser, lack of credit, costly credits, inappropriate markets for crops and a lack of technical skills.

The SSIS issues in relation to the scheme's age and size would have been important in informing our study, but unfortunately, there was limited literature examining how the schemes' characteristics in terms of age and size related to issues faced. A closely related study in Ethiopia (Ulsido \& Alemu, 2014) assessed the irrigation schemes' constraints based on their age. However, there was no noticeable difference in age issues affecting schemes. Moreover, there was very limited literature analysing these issues in terms of farm size, which some studies measured by the number of livestock on the farm or in terms of the surface area of the farm (Mengistie \& Kidane, 2016); Ulsido \& Alemu, 2014; Mutambara et al., 2016).

A review of the above studies provided insights into a range of factors affecting SSIS that required the attention of policymakers. Other studies analysed factors as a result of public debate on the debilitating effect of these factors. Some studies sought to identify the most important factors. For example, in Cambodia, de Silva et al. (2014) revealed that economic, social, environmental and legal factors were the most important constraints. In Nicaragua, Hallensleben (2012) reported social factors as the most important SSIS constraints. In the European Union, economic, social and environmental factors were more serious (Levidow et al., 2014). These studies revealed that the importance of SSIS constraints could vary from context to context, which motivated this study to focus on Zimbabwe. The country has a history of political turmoil related to farming, with land redistribution becoming a source of insecurity in the early part of the twenty-first century. Zimbabwe's political context in relation to farming is an indication that the importance of the factors among stakeholders is different from what has been observed elsewhere. There was also an economic decline in the country in the recent past, linked to land reform politics. Assessing 


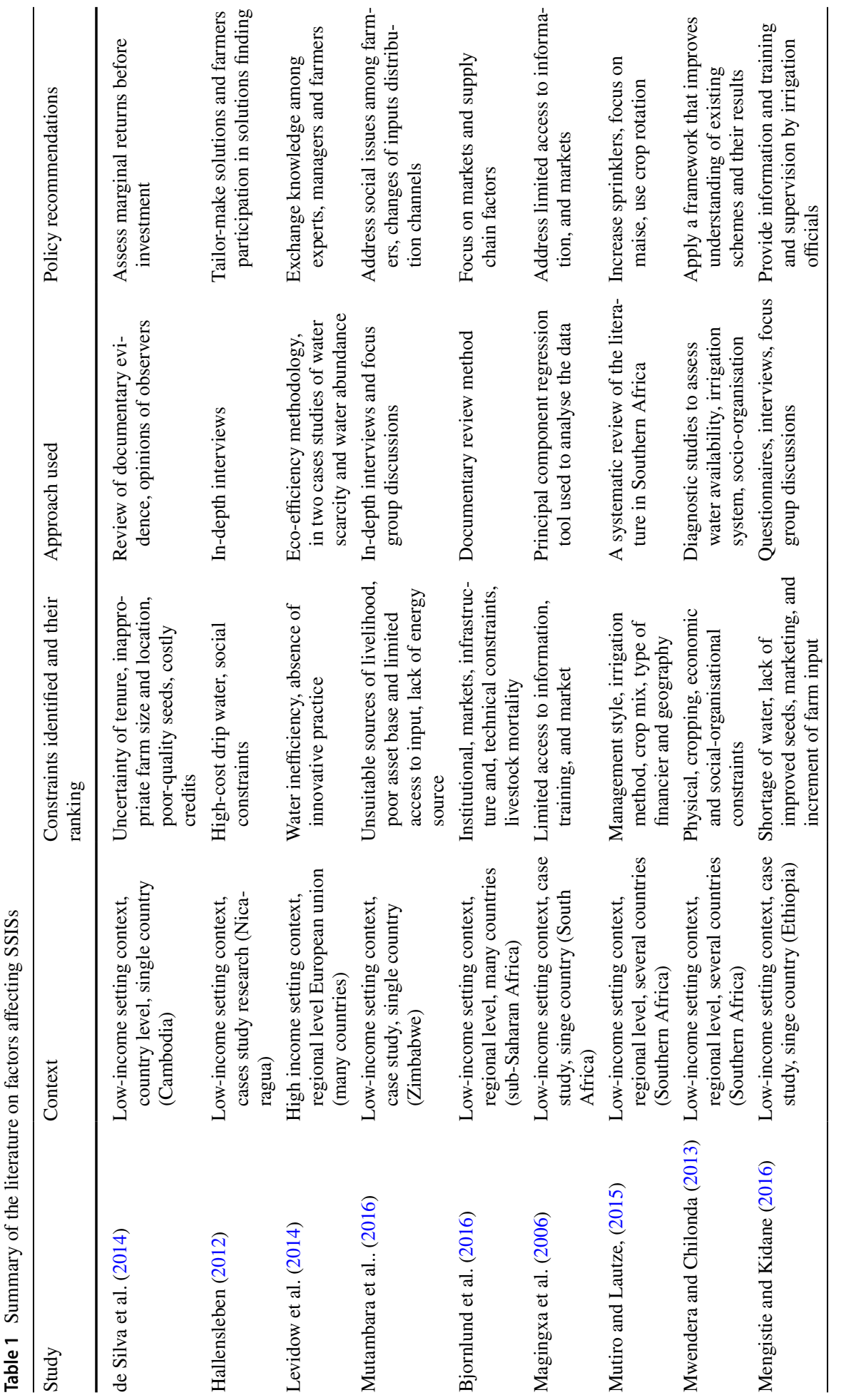




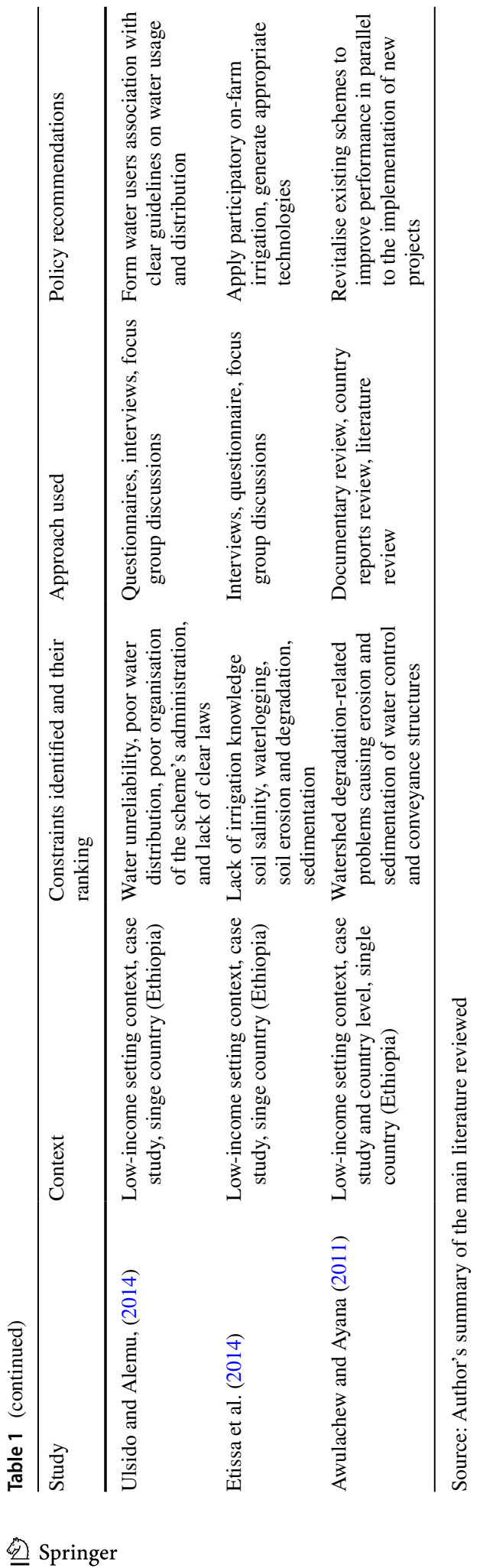


these factors within the context of Zimbabwe is the aim of this paper. The study also contributes to the literature by ranking factors, based on stakeholders' opinions and SSIS statistics, within the framework (PESTEL) that presents these factors in broader themes, notably political, environmental, social, technical, economic and legal. Other studies have mainly focused on individual factors within the broader themes. Finally, the study contributes to the literature by assessing the rankings of different features in four schemes to establish a discernible pattern. The contribution here is significant in that there is limited evidence available in this context.

\section{Conceptual framework}

The constraints encountered by any system and how they can be dealt with are best understood through the Theory of Constraints (TOC) by Goldratt (1984) as cited in Cox and Schleier (2010). The theory argues that there are constraints or at least a constraint in any system preventing the achievement of its set objectives. According to this theory, the goal of any project is to maximise the efficiency of its process at critical points, which optimise the profitability, quality or any other set objectives. Therefore, a constraint can be eliminated in the knowledge that its elimination does not perfect the system since some other factors become new and threatening constraints. According to the theory, the system will be stronger than before and not currently as strong as it could be. Hence, it advocates for the continuous improvement of the system's process where constraints have been identified. Once identified, the most critical constraints with the potential to yield immediate system improvement are addressed first at any given time. The gradual improvement would then prevent the spreading of limited resources across the entire system. In as much as this theory identifies constraints continuously and dynamically, this paper will not account for SSIS constraints in that manner but rather considers a cross-sectional analysis of the situation. The performance of the schemes can still be improved based on this particular approach, as there should be no specific point when SSIS are expected to operate below their efficiency levels.

The identification of constraints affecting SSIS operations as expounded by the TOC is contextualised in themes reflecting political, economic, social, technical, environmental and legal (PESTEL) perspectives. This paper attempts to get these perspectives of constraints ranked by irrigation stakeholders. The six themes are explained by the Asian Development Bank (ADB), (2016) as follows: Political constraints refer to barriers in terms of the lack of politicians' positive influence and include a lack of political will and support. Economic constraints refer to limited access to resources by the schemes, distorted markets and user fees. With reference to economic constraints, the scope of the paper does not extend to the analysis of farmers' individual economic outcomes, but how their level of exposure to economic resources affects farming in terms of SSIS inputs, water usage and infrastructure development. Economic constraints relate to resource access, while social constraints relate to the social environment, including conflicts related to irrigation water use, irrigation water thefts, unequal irrigation water distribution, and poor communication between irrigation stakeholders.

Technical constraints include the poor state of irrigation infrastructure, the lack of infrastructure maintenance, inadequate skills and knowledge of utilising irrigation systems, and poor irrigation management and service delivery. Legal constraints generally refer to an outdated and insufficient legal framework that works against irrigation operations. Finally, 
environmental constraints to irrigation operations encompass all issues arising from the surrounding environment, such as climate change, weather variability and SSIS' geography. The PESTEL framework helps identify factors that hinder or help an organisation's performance where, in this case, the organisations in question are SSIS (see Fig. 1). This framework is known through different models. For instance, it can be expressed as PEST, PESTLE, STEPLE, SLEPT or PEST-E, with all of these variants analysing key factors that impact an organisation's or firm's performance. These exogenous factors do not always carry the same weight, implying a need to rank them so that TOC can guide the strategic management of SSIS.

Furthermore, the PESTEL framework offers a systematic and holistic assessment of exogenous factors affecting SSIS operations. Therefore, using the framework in this study is justifiable because any system (including SSIS) faces broader external issues which affect its performance (Johnson et al., 2005), albeit not to the same extent. The difference in the effects of these factors implies that the constraints faced by SSIS need to be identified and ranked. That is the core objective of this study which aims to help promote the prosperity of SSIS and maximise the benefits the systems were created for.

\section{Materials and methods}

\subsection{Study area}

In line with the study's novel goal to offer policy-relevant suggestions to issues faced by SSIS, evidence is used from four case studies of farmer-managed SSIS, namely Mutema, Tawona, Bwerudza and Charuma. In the four examples, irrigation management committees are selected for a fixed term to manage SSIS operations, especially the collection of irrigation user fees that cover electricity charges, water levies, irrigation development levies and scheme maintenance fees amounting to US\$15 an acre. The four schemes are located in the drought-prone area of the Chipinge District in

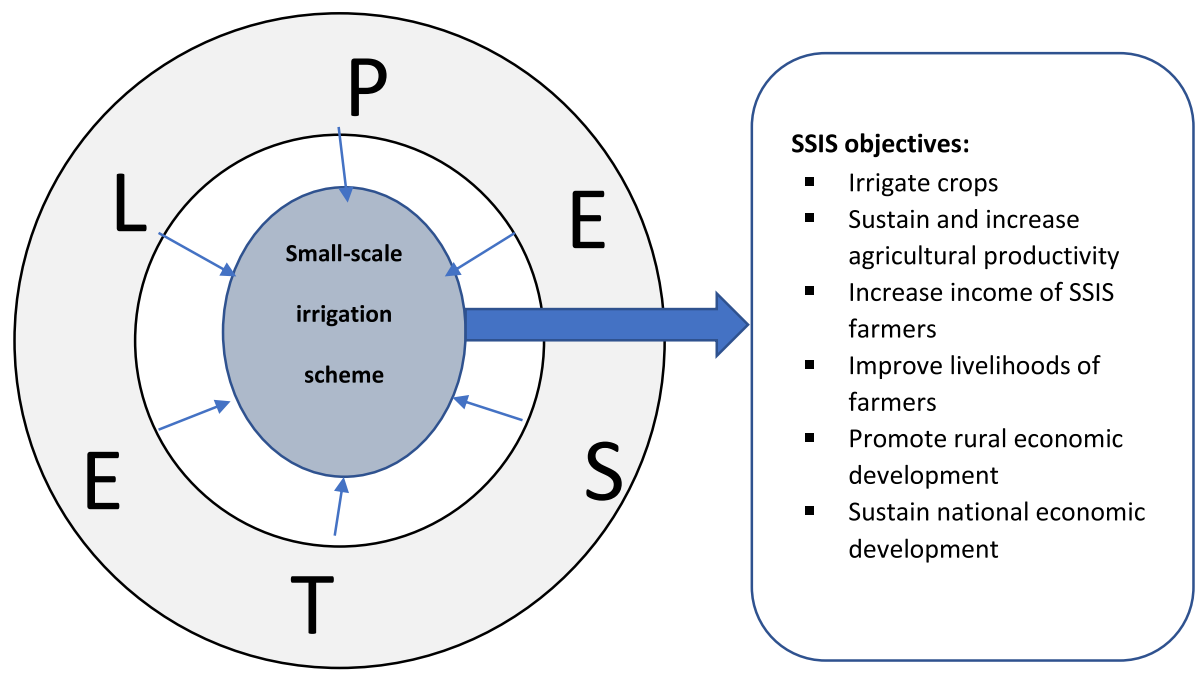

Fig. 1 Conceptual framework 
the province of Manicaland in Zimbabwe, which was purposely selected for this study because it has the most and oldest SSIS in the Manicaland province, providing a variety of examples of constraints as well as opportunities for the study to explain the limitations. Furthermore, the four SSIS considered in this paper are situated in natural region five under the administrative boundary of Ward 3, characterised by low annual rainfall (less than $450 \mathrm{~mm}$ a year), very high temperatures and severe food insecurity due to perennial droughts and prolonged dry spells. Working with four case studies in this area was ideal for identifying the various constraints smallholder irrigation schemes face in drought-prone regions.

The Mutema scheme was established in 1932 by missionaries using run-off water from the Tanganda River. Initially, the scheme provided irrigation for 70 ha, which was later increased to 180 ha. After 1980, the Zimbabwe Government adopted the scheme and currently has three blocks, but only Block 2 is fully functional.

Block 2 involves about 59.5 ha and is divided into plots ranging from 0.4 ha to 0.8 ha. In 2017, Block 2 had 238 farmers growing bananas on plots of an average area of 0.25 ha each. These farmers are actively involved in banana production under a contract farming arrangement using reduced hectarage. Consistent with this study's main objective, only Block 1 (the non-functional-irrigation system) and Block 3 (partially functional as it relies on the seasonal Tanganda River for irrigation water supply) were considered ideal for the study. Block 2, which is under viable contract farming, was excluded in this study due to data not being supplied by the contractor. Crops grown previously in both blocks under study included onions, cotton, tomatoes and maise. The main irrigation water sources are the seasonal Tanganda River and boreholes sunk for sprinkler irrigation in 1972. The Mutema irrigation scheme has the potential to irrigate 180 ha of land if the other two idle blocks become fully functional. About 121 ha has been unproductive since 2002 as farmers cannot rely on rainfall, which is the case in most years.

The Tawona scheme-established in 1954 - is a 278.4 ha scheme with 696 plots for 580 registered farmers, each allocated a 0.4 ha plot. Twenty hectares of land within the scheme lies idle due to a shortage of irrigation water. The scheme, located on the Save River bank, has sodic and alluvial soils with patchy areas of sandy soils, drawing its irrigation water directly from the river. A farmer-managed operation uses a flood irrigation system in which each farmer is billed a flat charge of US\$15 a month per acre-thus, the price is not calculated on the amount of water used. Crops grown include maise, tomatoes, wheat and sugar beans. The production system involves resident agricultural technical and extension (Agritex) officers preparing cropping calendars which the plot holders follow for the year.

The third case study, the Bwerudza scheme, was established in 2006 with a total land allocation of 158 ha and now involves 403 farmers. The scheme is divided into five blocks with an average-plot size of 0.3 ha. With its main source of irrigation water being the Tanganda River, the scheme irrigates only winter crops due to the shortage of irrigation water, while rain feeds summer crops. Onions and beans are grown, and occasionally tomatoes.

The Charuma irrigation scheme, conceived in 1998 but abandoned in 2008, was also included in this study. Located on the banks of the Save River it comprised 54 ha and provided 135 farmers with average plot sizes of 0.4 ha. A further 100 ha with the potential to be developed for irrigation was available for another 250 farmers on 0.4 ha plots. However, after infield and perimeter infrastructure were constructed, the project failed to take off-hence the need for this study to further investigate the issues. 


\subsection{Study samples and data collection methods}

This is a mixed research study using a structured questionnaire as an instrument for collecting quantitative data. Key informant interviews (KII), focus group discussions (FGD) and field observations were used to gather qualitative data to extract important and diverse information on constraints affecting the performance of SSIS from the perspective of stakeholders. The use of mixed methods is highly encouraged in research as it reduces each data collection method's limitations by removing biases associated with using a single method in research (Bryman, 2008).

A stratified sampling technique was used for the Tawona irrigation scheme, subdividing it into three segments - top, middle and bottom — as shown in Table 2.

The Cochran (1977) sample size determination formula helped decide the minimum sample size to interview. The researchers interviewed 313 irrigators out of a total of 580 individuals. Proportional stratified samples from the Tawona irrigation scheme were used. The research obtained survey data from the list of all irrigating farmers, which in turn came from agricultural technical and extension authorities. A farmer was taken as the basic survey unit for the 2016/2017 season's farming activities. From the irrigators' list, farmers are stratified according to their location on the irrigation scheme section, either head end, middle or tail end. After identifying these strata, a simple random sampling procedure was applied to select farmers in each irrigation scheme's section. Farmers who participated in focus group discussions and in-depth interviews were excluded from the questionnaire administration to eliminate bias in collected data. A questionnaire was designed to capture irrigation data relevant to this study's quantitative technique, such as the demographics, socio-economic data and details about irrigation water distribution, pricing and governance. To improve the quality of the research data, the questionnaire was administered by trained interviewers. The questionnaire was also pre-tested at the Birchenough Bridge irrigation scheme, which falls under the same agricultural farming region as the area in the study.

Information was gathered from five focus group discussions (FGD) with the farmerstwo at Tawona and one each at the Bwerudza, Mutema and Charuma schemes. Farmers were sampled in groups of between eight and 12 to assist in the smooth running of the discussions. Focus groups comprised both male and female farmers above the age of 40 with not less than ten years of continuous irrigation experience. FGD sessions took an hour on average to complete, with the researchers facilitating discussions with minimum interference. The facilitators started with a clear theme communicated to research participants and a set agenda of items/or questions derived from both the TOC and PESTEL framework. The groups worked through the FGD guide, with facilitators pursuing novel issues as they arose. The facilitators ensured everybody was allowed to express their views freely that

Table 2 Frequency distribution of farmers' population and sample data

\begin{tabular}{llc}
\hline Scheme location & Population size & Sample size \\
\hline Head & 180 & 114 \\
Middle & 273 & 124 \\
Tail & 127 & 75 \\
Total & 580 & 313 \\
\hline
\end{tabular}

Source: Survey data (2017) 
participants respected and avoided offending each other during the discussions and that the discussions were focused.

On the other hand, KII were purposively carried out with stakeholders with background information on irrigation development. Interviews were held with staff from the Department of Irrigation, Agritex, the Zimbabwe Water Authority, Irrigation Management Committee (IMC) members and the community leadership in all SSIS studied. Key informant guides were used to gather views on SSIS-performance-related issues. The open-ended nature of the KII and FGD allowed for more reflection and opportunities in identifying underlying factors perceived by the respondents to constrain SSIS' operations. Responses were recorded in research diaries and on audio files.

The study also used the participant observation method to obtain more information on main irrigation canals, crop production, catchment management, plots, infield infrastructure, water sources and pump houses, and environmental degradation, among other issues. This was a way of buttressing the outcomes of the KII and FGD.

In all discussions, stakeholders were asked to rank constraints they identified from 1 to 6 , with 1 identifying the most significant issue and 6 the least significant factor. The coding of 1 to 6 was derived from the six factors presented in the PESTEL framework, where the factors are not ranked. The collected data were then integrated to respond to the demands of the study.

It is important to note that ethical considerations such as consent, confidentiality, participants' protection and withdrawal from participation were duly observed and implemented in the study. The data were collected between August and December 2017, with the University of KwaZulu-Natal issuing ethical clearance for the study.

\subsection{Data analysis}

The study obtained feedback on constraints more generally and in ranked form from irrigation stakeholders in the area. Quantitative data were processed using descriptive statistics, in particular, the frequency tables and cross-tables. Pre-coded qualitative data were analysed, guided by the thematic analysis technique, a qualitative research method that identifies, analyses and reports patterns or themes in qualitative data. These themes capture something important about the data concerning the research question and represent some level of patterned responses (Braun \& Clarke, 2006). According to this technique, an individual needs to follow these six steps when using a thematic approach: (1) become familiar with data being used; (2) generate initial codes; (3) search for themes; (4) review themes; (5) define and name themes and (6) produce the report. Following the conceptual framework of this study, the PESTEL framework is regarded as a thematic network. As such, it was prudent to apply the thematic analysis to the qualitative data of this study.

\section{Results and discussion}

Given that quantitative and qualitative research approaches were used in this paper to understand constraints on SSIS in the study area, the first and second sections present results based on the quantitative approach using the Tawona irrigation scheme as a case study. The third and last part of this section presents results based on qualitative data. The aim of the blended research approach is to gain a better understanding of the issues being studied. 


\subsection{Summary of irrigation-related outcomes}

As indicated in Table 3, most of the irrigation farmers are male and more than half of those interviewed are married. Their average age is around 53, and they have an average of about 19 years' of irrigation farming experience, which places them in the "mature bracket". There is an average of six family members in their households - a relatively larger family size-and their highest level of education is a secondary school (54\%). The literacy level of these farmers resonates well with their higher levels of agricultural networking, as evidenced by the majority of them either belonging to farmers' groups $(56 \%)$ and participating in agricultural training (66\%) or agricultural research activities (72\%).

Of the farmers studied, $99 \%$ agreed that irrigation farming is important to their livelihoods which is reflected in their support for irrigation farming in the dry areas of Zimbabwe and their realisation of its significant contribution to food security and income generation (see Table 4).

\subsection{Constraints faced by Tawona irrigation farmers}

Although farmers interviewed realised the importance of irrigation farming for food security and income generation, most of them cannot access funds needed for farming from formal institutions. The majority (65\%) do not have access to formal credit.

Table 3 Summary of descriptive statistics of farmers' characteristics

\begin{tabular}{|c|c|c|}
\hline Variable Groups & & Proportion/mean \\
\hline \multirow[t]{2}{*}{ Gender } & Male & 0.59 \\
\hline & Female & 0.41 \\
\hline \multirow[t]{4}{*}{ Marital status } & Single & 0.01 \\
\hline & Married & 0.73 \\
\hline & Widowed & 0.25 \\
\hline & Separated/divorced & 0.01 \\
\hline \multirow[t]{5}{*}{ Education } & Not educated & 0.13 \\
\hline & Adult education & 0.02 \\
\hline & Primary & 0.30 \\
\hline & Secondary & 0.54 \\
\hline & Tertiary & 0.02 \\
\hline \multirow[t]{2}{*}{ Farmers agricultural training } & Yes & 0.66 \\
\hline & No & 0.44 \\
\hline \multirow[t]{2}{*}{ Agricultural research participation } & Yes & 0.72 \\
\hline & No & 0.28 \\
\hline \multirow[t]{2}{*}{ Farmers' group } & Yes & 0.56 \\
\hline & No & 0.44 \\
\hline Age & $\ldots$ & 53.18 \\
\hline Household size & $\ldots$ & 5.67 \\
\hline Farming experience & $\ldots$ & 19.26 \\
\hline Loan size & $\ldots$ & 47.95 \\
\hline Sample size & & 313 \\
\hline
\end{tabular}

Source: Field survey (2017) 
Table 4 Percentage of frequency table showing the contribution of irrigation to farmers' livelihoods

\begin{tabular}{lc}
\hline Irrigation benefits & $\begin{array}{c}\text { Percentage of } \\
\text { respondents }\end{array}$ \\
\hline Food security only & 21 \\
Income generation only & 11 \\
Education for family members only & 1 \\
Food security and income generation & 43 \\
Food security and education for family members & 17 \\
Food security and employment creation & 1 \\
All of the above & 6 \\
Total & 100 \\
\hline
\end{tabular}

Source: survey data (2017)

The $35 \%$ of farmers who have access to credit got an average of US\$47.95, which is relatively insignificant for meaningful agricultural production. With only just over half of the farmers indicating their soil was fertile enough for irrigation farming, the importance of agricultural finance in uplifting the livelihoods of irrigation farmers cannot be overemphasised.

Table 5 presents farmers' perceptions of irrigation water distribution. Even though the majority of farmers (63\%) revealed that they receive adequate water for their crops, its spatial distribution is a major concern. About $51 \%$ of farmers receiving adequate water are located in the middle of the scheme, while $43 \%$ of the farmers receiving adequate water are situated in the scheme head and around 7\% in the scheme tail. This suggests water adequacy variation according to plot location, which worsens at the tail end of the scheme. This trend is also evident in equitable irrigation water distribution, where most farmers $(70 \%)$ perceived water distribution as equitable. However, this again varies with the location of the plot in the scheme. This is evidenced by around $40 \%$ of farmers in the top and middle section of the scheme perceiving equity in water distribution, with only a few (11\%) farmers at the tail-end agreeing. On irrigation water reliability, a few tail-end farmers (7\%) indicated satisfaction with the service against a combined percentage (93\%) of farmers in the middle and head agreeing. Irrigation water distribution thus varies across the scheme in terms of adequacy, equity and reliability. The tail-end irrigation farmers perceive irrigation water as inadequate, inequitable and unreliable in sharp contrast to their counterparts located in the upper stream. This may

Table 5 Cross-tabulation of farmers' perceptions on water distribution

\begin{tabular}{|c|c|c|c|c|c|c|c|c|}
\hline \multirow[b]{2}{*}{ Plot location } & \multicolumn{2}{|c|}{ Water adequacy } & \multicolumn{2}{|c|}{ Water equity } & \multicolumn{2}{|l|}{ Water reliability } & \multicolumn{2}{|c|}{$\begin{array}{l}\text { Water con- } \\
\text { flicts }\end{array}$} \\
\hline & No & Yes & No & Yes & Unsatisfactory & Satisfactory & No & Yes \\
\hline Head & 30 & 84 & 25 & 89 & 48 & 66 & 44 & 70 \\
\hline Middle & 24 & 100 & 20 & 104 & 29 & 95 & 93 & 31 \\
\hline Tail & 63 & 12 & 52 & 23 & 62 & 13 & 9 & 66 \\
\hline Total & 117 & 196 & 97 & 216 & 139 & 174 & 146 & 167 \\
\hline
\end{tabular}

Source: Survey data (2017) 
Table 6 Contingency table for farmers' perceptions on water pricing

\begin{tabular}{lrrrrrr}
\hline & \multicolumn{2}{l}{$\begin{array}{l}\text { Water pricing satisfac- } \\
\text { tion }\end{array}$} & & \multicolumn{2}{l}{ Water pricing perception } & \\
\cline { 2 - 3 } \cline { 5 - 6 } Plot location & No & Yes & & Not expensive & Expensive & Very expensive \\
\hline Head & 81 & 33 & & 31 & 44 & 39 \\
Middle & 101 & 23 & & 23 & 64 & 37 \\
Tail & 70 & 5 & & 1 & 111 & 71 \\
Total & 252 & 61 & 55 & & 37 \\
\hline
\end{tabular}

Source: Survey data (2017)

Table 7 Cross-tabulation of farmers' perceptions on water governance

\begin{tabular}{|c|c|c|c|c|c|c|c|}
\hline \multirow[b]{2}{*}{ Plot location } & \multicolumn{2}{|c|}{ Accountability } & \multicolumn{2}{|c|}{ Transparency } & \multicolumn{3}{|c|}{ Irrigation maintenance culture } \\
\hline & No & Yes & No & Yes & Not maintained & $\begin{array}{l}\text { Poorly main- } \\
\text { tained }\end{array}$ & $\begin{array}{l}\text { Well } \\
\text { main- } \\
\text { tained }\end{array}$ \\
\hline Head & 50 & 64 & 31 & 83 & 39 & 43 & 32 \\
\hline Middle & 21 & 103 & 21 & 103 & 16 & 94 & 14 \\
\hline Tail & 35 & 40 & 31 & 44 & 4 & 64 & 7 \\
\hline Total & 106 & 207 & 83 & 230 & 59 & 201 & 53 \\
\hline
\end{tabular}

Source: Survey data (2017)

explain irrigation water conflicts that are dominant in this scheme, where around $40 \%$ of farmers agreed to the existence of these conflicts in the scheme's extreme locations.

The study further explored issues related to water pricing to understand the sustainability of SSIS. It is important to emphasise that without water, there is no irrigation. Therefore the price of irrigation water can be a factor ensuring its availability to farmers. How irrigation farmers perceive the irrigation water price can also affect the financial position of the scheme. If farmers perceive it as expensive relative to their income levels, they may not pay their bills, thus affecting irrigation water supply. As shown in Table 6, most farmers that is 252 out of $313(81 \%)$ are dissatisfied with irrigation water pricing, while 47\% (147/313) believe it is very expensive. This has negative implications on a scheme's sustainability.

Perceptions about irrigation scheme water governance and maintenance culture, as shown in Table 7, indicate that the majority of farmers agreed that the scheme management is both transparent (74\%) and accountable (64\%) in its irrigation operations, which is good for the sustenance and sustainability of scheme operations as good governance assists in scheme development. However, a contradiction surfaces when most farmers (83\%) indicate a poor irrigation maintenance culture. Although scheme maintenance involves all stakeholders at the scheme level, the responsibility of enforcing this lies with the irrigation scheme management.

In a nutshell, the empirical evidence from the quantitative analysis reveals the huge impact of the economic constraints of credit accessibility and irrigation water pricing issues and, to a lesser extent, the impact of social (water distribution issues), technical (irrigation maintenance status and water governance issues) and environmental (soil fertility) 
constraints, as weighted by the percentage frequencies acknowledging their existence at the Tawona scheme.

\subsection{Constraints faced by the four small-scale irrigation schemes}

The qualitative study of the schemes involved stakeholders stating and ranking constraints faced by their respective SSIS in order of severity, starting with the most significant and ending with the least significant.

The major constraint faced by SSIS as ranked by farmers is technically related. In particular, the irrigation management committee's (IMC) lack of technical know-how was cited as a major issue. Farmers report that the IMC does not have pump-spare parts. There is no regular and efficient maintenance done on the pumps, resulting in frequent breakdowns, causing unreliable irrigation water supplies. This problem is prevalent in the Tawona scheme.

Another technical problem is the unsatisfactory state of irrigation infrastructure. Farmers raised issues related to poor irrigation infrastructural design and conveyance systems as witnessed by the absence of water reservoirs and proper suction points causing siltation of canals. Additionally, there is derelict and damaged irrigation infrastructure, and the situation has been exacerbated by a poor scheme maintenance culture, especially at the Tawona and Mutema irrigation schemes. Leakages, seepage and irrigation water losses are widespread, resulting in the limited irrigation water supply as witnessed at the Tawona scheme. Discussions with stakeholders also revealed poor site support infrastructure, with an example being the porous perimeter fence that enables stray animals to move through the area. They also reported poor feeder roads and a lack of site infrastructure such as storage facilities, water and sanitation, impacting farmer-extension officers. There was also a lack of transport facilities for Agritex officers, affecting their response to serious challenges. The study finding that technical constraints impact the functioning and efficiency of SSIS in Zimbabwe is in line with the research results of Nkambule and Dhlamini (2013f), Manzungu (1995), Moyo et al. (2016), Mdemu et al. (2016),

Adam et al. (2016), Oriola (2009) and Dinye (2013).

The second most serious constraint from the perspective of stakeholders is the high cost of irrigation, especially at the Tawona and Bwerudza SSIS, where the fee of US\$15 per plot is a serious economic challenge faced by farmers and has resulted in most of them being unwilling to pay, followed by cumulative non-paid fees causing a legacy debt. Focus group discussions revealed that the legacy debt was US\$69 000 as of 31 December 2017, after accumulating since 2010. Non-payment of bills results in disruptions in irrigation water supplies as service providers discontinue the feed with such issues threatening the financial viability of SSIS. As highlighted by stakeholders, a further economic challenge involves poor agronomic practices by farmers such as poor crop choices and lack of crop diversification, often leading to simultaneous over/underproduction and harvesting of similar crops, lack of modern farming techniques and poor crop pests and disease control. Consequentially, massive produce losses are experienced by farmers. Another economic challenge reported by farmers is the lack of markets. On the supply side, they highlighted problems such as a lack of formal credit, high input costs and lack of input-support schemes, forcing some farmers to engage in unfair contract farming. From the demand side, farmers noted with concern that the Zimbabwean economy's shrinking manufacturing sector in recent years has had adverse effects on their farming activities in the form of a lack of markets or depressed markets for farm produce. In most cases, farmers reported 
that their produce ended up fetching low prices, causing massive losses. Findings that economic issues impact the performance of SSIS equate with those of de Silva et al. (2014), Adam et al. (2016), Dinye (2013), Chibisa et al. (2008), Fanadzo (2012), among others.

Management and irrigation beneficiaries ranked social constraints as the next most serious, especially the prevalence of wildlife-human conflicts that lead to crop destruction and irrigation infrastructure vandalism. This was noted as an issue of concern at the Tawona irrigation scheme.

Furthermore, a poor irrigation water management system was cited as causing inequitable water distribution where conflict over irrigation water use and rampant water theft resulted. Inefficient irrigation water management has adverse effects on crop production. Study findings are in line with the research results of de Silva et al. (2014), Adam et al. (2016), Dinye (2013), Nkambule and Dhlamini (2013), Fanadzo (2012) that show that social issues related to irrigation activities hinder smooth SSIS operations.

According to stakeholders, environmental challenges were the next most serious. One of the notable challenges was that of soil erosion resulting in siltation issues. The Tawona pump house is under threat of being washed away by the Save River because of serious soil erosion on its banks. Soil erosion also leads to siltation of suction points at the Tawona irrigation pump house and siltation of storm drains protecting most SSIS, and this can cause flooding of the plots. Related to this, stakeholders reported a lack of a proper de-siltation service at the suction point and serious implications for the irrigation pumping system. For example, due to serious sand-siltation problems at suction points, sucked sand scrapes asbestos pipes reducing their lifespan and the pump rate. Another challenge reported was soil salinity from borehole water used in the Mutema irrigation scheme, leading to poor soil quality. Unconventional tillage methods used by most farmers were reported as causing sloppy plots (Bwerudza irrigation scheme) and soil panning (Mutema and Tawona SSIS). A further environmental challenge highlighted is the impact of climate change, such as frequent droughts that reduce river-water discharge (Tawona, Mutema and Bwerudza schemes) and cyclones that destroy irrigation infrastructure. The study findings concur with de Silva et al. (2014) and Fanadzo (2012), where the environment constrains the performance of the schemes.

Legal issues surrounding irrigation operations were ranked fifth most serious. Specifically, KII at the Mutema and Tawona schemes revealed that they use an old, English-version irrigation water constitution, which very few farmers understand. Due to this ignorance of the law, there is a rampant violation of the water management's constitution, especially at the Tawona scheme. As noted in the discussions, election processes for irrigation committee members do not respect by laws and the constitution, with election procedures being chaotic in most cases. Farmers lamented the lack of legal representation they receive when irrigation-related conflicts end up in the courts. All these legal issues harm SSIS operations. The study finding that the legal environment negatively affects SSIS' operations in Zimbabwe is in agreement with research results by de Silva et al. (2014), Moyo et al. (2016) and Nkambule and Dhlamini (2013).

As reported by key stakeholders in the study, the lowest ranked constraint involves SSIS irrigation operations and political issues. One of the issues concerned poor project planning by the government, resulting in a lack of local community involvement in project setups. The other constraints reported are lack of government funding and development-will coupled with poor public-private partnerships (PPP) in SSIS development. This has been the case at Charuma (idle) and Mutema (dysfunctional) for more than 20 years. Manzungu (1995) and Fanadzo (2012) also identified politics as inhibiting SSIS development. 


\section{Conclusions and recommendations}

This paper shows that the irrigation farming community benefits from the irrigation schemes, but several constraints hinder them from operating to their full potential. The outlined evidence stems from a PESTEL framework perspective presenting ranked constraints SSIS face from the beneficiary perspective and Zimbabwe's drought-prone areas. These constraints, as outlined by stakeholders in order of importance, are: technical, economic, social, environmental, legal and political. Specific types of constraints under each broad theme were also outlined. In contrast to some expectations, political factors did not emerge as important despite recent land redistribution policies, which created insecurity.

Furthermore, there were no discernable patterns relating to the importance of factors across the different characteristics of the schemes. However, it is important to note that the results concur with evidence in many SSIS constraints literature. The paper contributed to the literature by ranking constraints in broader categories, as suggested by the PESTEL framework. These findings enrich the literature on SSIS' constraints by highlighting the limitation of irrigation schemes in drought-prone areas in Zimbabwe. Understanding how stakeholders rank constraints may help government and development partners to address them. The ranking is motivated by the fact that resources and means are not always available to sort out the concerns.

The Theory of Constraints argues that any system is faced by constraints or at least a constraint that prevents it from attaining its full performance level. The theory implies that the SSIS studied here should first address the major constraint, which is the technical limitation involved. However, the theory reveals that limitations are addressed in sequences to perfect the operations of the SSIS, with other constraints being addressed subsequently. Accordingly, Zimbabwe's Government must continue providing technical support for existing SSIS whilst promoting the establishment of similar projects in Zimbabwe's drought-prone areas.

This study suggests several strategic actions irrigation stakeholders (government, farmers and private partners) should consider implementing in the face of identified operational challenges. They include:

- Modernising SSIS as a priority to solve the constraints hampering schemes that were studied

- Training farmers and exposing them to the latest in farming techniques to sustain SSIS operations in the long term

- Promoting fair contract farming, providing access to investment finance, organising guaranteed markets; setting-up local processing plants to minimise agricultural produce losses; assisting with low-cost inputs, and harmonising irrigation user fees to enhance SSIS sustainability

- Involving local communities in all stages of smallholder irrigation scheme development

- Establishing a government-development partners-SSIS platform where periodic and public reviews of irrigation policies and issues affecting SSIS are negotiated

- Harnessing underutilised solar energy (solar pumps), tapping into underground water and damming seasonal rivers to create reservoirs to sustain the supply of irrigation water

- Resolving human-wildlife conflicts in farming regions by erecting electric fencing around game parks and reserves 
Although evidence about SSIS constraints presented in this study was gained specifically from four case studies using the PESTEL framework, it proved to be insightful and far-reaching, providing in-depth, broad and holistic rankings to assist in understanding the importance of SSIS' constraints in drought-prone areas in Zimbabwe and helping to craft effective policies which could assist development in the irrigation industry.

Acknowledgements The study acknowledges the cooperation from all irrigation stakeholders involved in this study, especially the small-scale irrigation farmers.

Funding Not applicable.

Availability of data and material (data transparency) Not applicable.

Code availability (software application or custom code) Not applicable.

\section{Declarations}

\section{Conflict of interest None.}

Open Access This article is licensed under a Creative Commons Attribution 4.0 International License, which permits use, sharing, adaptation, distribution and reproduction in any medium or format, as long as you give appropriate credit to the original author(s) and the source, provide a link to the Creative Commons licence, and indicate if changes were made. The images or other third party material in this article are included in the article's Creative Commons licence, unless indicated otherwise in a credit line to the material. If material is not included in the article's Creative Commons licence and your intended use is not permitted by statutory regulation or exceeds the permitted use, you will need to obtain permission directly from the copyright holder. To view a copy of this licence, visit http://creativecommons.org/licenses/by/4.0/.

\section{References}

Aberra, Y. (2004). Problems of the solution: Intervention into small-scale irrigation for drought proofing in the Mekele Plateau of Northern Ethiopia. The Geographical Journal, 170(3), 226-237. https://doi.org/ 10.1111/j.0016-7398.2004.00122.x

Adam, J. N., Al-hassan, S., \& Akolgo, D. A. (2016). Small-scale Irrigation and Rural Poverty Reduction in the Upper-East Region of Ghana. African Journal of Science and Research, 2(5), 38-42.

Asian Development Bank, ADB. (2016). Revitalising Irrigation Performance: Lessons from Asia. 2nd Asian Irrigation Forum. 2nd Asian Irrigation Forum, Asian Development Bank, Manila, Philippines. https://events.development.asia/system/files/materials/2015/11/201511-revitalizing-irrig ation-performance-lessons-asia-region.pdf

Awulachew, S. B., \& Ayana, M. (2011). Performance of irrigation: An assessment at different scales in Ethiopia. Experimental Agriculture, 47(S1), 57-69. https://doi.org/10.1017/S0014479710000955

Ayele, G. K. (2011). The impact of selected small-scale irrigation schemes on household income and the likelihood of poverty in the Lake Tana Basin of Ethiopia. Cornell University.

Bjornlund, H., van Rooyen, A., \& Stirzaker, R. (2016). Profitability and productivity barriers and opportunities in small-scale irrigation schemes. International Journal of Water Resources Development, 33(5), 1-15. https://doi.org/10.1080/07900627.2016.1263552

Braun, V., \& Clarke, V. (2006). Using thematic analysis in psychology. Qualitative Research in Psychology, 3(2), 77-101.

Bryman, A. (2008). Social research methods (Third Edition). Oxford University Press.

Charles, H., Godfray, J., Beddington, J., R., Crute, I., R., Haddad, L., David, L., Muir, J., F., Pretty, J., Robinson, S., Thomas, S., M., \& Toulmin, C. (2010). Food security: The challenge of feeding 9 billion people. Science, 327(5967), 812-818.

Chibisa, P., Mautsa, A., \& Mukoto, B. (2008). Smallholder irrigation schemes in Nyanga North as strategies for poverty reduction and sustainable rural livelihoods. Journal of Sustainable Development in Africa, $10(2), 653-676$. 
Chikozho, C. (2010). Applied social research and action priorities for adaptation to climate change and rainfall variability in the rain-fed agricultural sector of Zimbabwe. Physics and Chemistry of the Earth, Parts a/b/c, 35(13-14), 780-790. https://doi.org/10.1016/j.pce.2010.07.006

Climate-Smart Agricultural Manual for Zimbabwe. (2017). For Agriculture Education in Zimbabwe. Climate Technology Centre and Network, Denmark.

Cochran, W. G. (1977). Sampling techniques (Third Edition). Wiley.

Cox, J. F., \& Schleier, J. G. (2010). Theory of constraints handbook. McGraw-Hill. http://accessengi neeringlibrary.com/browse/theory-of-constraints-handbook

de Silva, S., Johnston, R., \& Sellamuttu, S. S. (2014). Agriculture, irrigation and poverty reduction in Cambodia: Policy narratives and ground realities compared [Working Paper AAS-2014-13].

Descheemaeker, K., Zijlstra, M., Masikati, P., Crespo, O., \& Homann-KeeTui, S. (2018). Effects of climate change and adaptation on the livestock component of mixed farming systems: A modelling study from semi-arid Zimbabwe. Agricultural Systems, 159, 282-295. https://doi.org/10.1016/j. agsy.2017.05.004

Dinye, R. (2013). Irrigated agriculture and poverty reduction in Kassena Nankana district in the upper-East region, Ghana. Journal of Science and Technology (Ghana), 33(2), 59-72. https://doi.org/10.4314/just. v33i2.6.

Etissa, E., Dechassa, N., Alamirew, T., Alemayehu, Y., \& Desalegne, L. (2014). Irrigation water management practices in smallholder vegetable crops production: the case of the central rift valley of Ethiopia. Science, Technology and Arts Research Journal, 3(1), 74-83. https://doi.org/10.4314/star.v3i1.13.

Fanadzo, M. (2012). Revitalisation of smallholder irrigation schemes for poverty alleviation and household food security in South Africa: A review. African Journal of Agricultural Research, 7(13). https://doi. org/10.5897/AJARX11.051.

FAO. (2000). Socio-economic Impact of Smallholder Irrigation Development in Zimbabwe: Case studies of ten irrigation schemes. Food and Agriculture Organisation, United Nations, Harare, SAFR/AGLW/ DOC/OO2.

Goldratt, E. M. (1984). Theory of Constraints. Croton-on-Hudson: North River Press.

Gwimbi, P. (2009). Cotton farmers' vulnerability to climate change in Gokwe District (Zimbabwe): Impact and influencing factors. JAMBA: Journal of Disaster Risk Studies, 2(2), 81-92. https://doi.org/10. 4102/jamba.v2i2.17

Hallensleben, N. (2012). Characterising Poor Smallholder Farmers in Nicaragua: Factors Influencing the Success or Failure of Micro-irrigation Users [Master's Thesis (Unpublished)]. University of St. Gallen (HSG).

Hussain, I., \& Hanjra, M. A. (2004). Irrigation and poverty alleviation: Review of the empirical evidence. Irrigation and Drainage, 53(1), 1-15. https://doi.org/10.1002/ird.114.

IFPRI. (2006). How Will Agriculture Adapt to the Shifting Climate? International Food Research Institute and Its 2020 Vision Initiative, Washington DC.

IPCC. (2013). Summary for Policymakers. In Climate Change (Stocker, T.F., D. Qin, G.-K. Plattner, M. Tignor, S.K. Allen, J. Boschung, A. Nauels, Y. Xia, V. Bex and P.M. Midgley). Cambridge University Press, Cambridge,.

Johnson, G., Scholes, K., \& Whittington, R. (2005). Exploring corporate strategy (7th ed.). FT/Prentice Hall.

Kinsey, B., Burger, K., \& Gunning, J. W. (1998). Coping with drought in Zimbabwe: Survey evidence on responses of rural households to risk. World Development, 26(1), 89-110. https://doi.org/10.1016/ S0305-750X(97)00124-1

Levidow, L., Zaccaria, D., Maia, R., Vivas, E., Todorovic, M., \& Scardigno, A. (2014). Improving waterefficient irrigation: Prospects and difficulties of innovative practices. Agricultural Water Management, 146, 84-94. https://doi.org/10.1016/j.agwat.2014.07.012.

Magingxa, L. L., Alemu, Z. G., \& Herman Daniël van Schalkwyk. (2006). Factors influencing the success potential in smallholder irrigation projects of South Africa: A principal-component regression. (No. 1004-2016-78553).

Makaudze, E. M., \& Miranda, M. J. (2010). Catastrophic drought insurance based on the remotely sensed normalised difference vegetation index for smallholder farmers in Zimbabwe. Agrekon, 49(4), 418432. https://doi.org/10.1080/03031853.2010.526690

Makuvaro, V., Walker, S., Masere, T. P., \& Dimes, J. (2018). Smallholder farmer perceived effects of climate change on agricultural productivity and adaptation strategies. Journal of Arid Environments, 152, 75-82. https://doi.org/10.1016/j.jaridenv.2018.01.016.

Manzungu, E. (1995). Engineering or domineering? The politics of water control in Mutambara irrigation scheme, Zimbabwe. Zambezia, XXII(ii), 22. 
Mdemu, M. V., Mziray, N., Bjornlund, H., \& Kashaigili, J. J. (2016). Barriers to and opportunities for improving productivity and profitability of the Kiwere and Magozi irrigation schemes in Tanzania. International Journal of Water Resources Development, 33(5), 725-739. https://doi.org/10.1080/ 07900627.2016.1188267.

Mengistie, D., \& Kidane, D. (2016). Assessment of the impact of small-scale irrigation on household livelihood improvement at Gubalafto District, North Wollo, Ethiopia. Agriculture, 6(3), 1-22. https://doi. org/10.3390/agriculture6030027

Mertz, O., Mbow, C., Reenberg, A., \& Diouf, A. (2009). Farmers' perceptions of climate change and agricultural adaptation strategies in rural sahel. Environmental Management, 43(5), 804-816. https://doi. org/10.1007/s00267-008-9197-0

Moyo, M., van Rooyen, A., Moyo, M., Chivenge, P., \& Bjornlund, H. (2016). Irrigation development in Zimbabwe: Understanding productivity barriers and opportunities at Mkoba and Silalatshani irrigation schemes. International Journal of Water Resources Development, 33(5), 740-754. https://doi.org/10. 1080/07900627.2016.1175339

Mutambara, S., Darkoh, M. B. K., \& Atlhopheng, J. R. (2016). A comparative review of water management sustainability challenges in smallholder irrigation schemes in Africa and Asia. Agricultural Water Management, 171, 63-72. https://doi.org/10.1016/j.agwat.2016.03.010

Mutambara, S., \& Munodawafa, A. (2014). Production challenges and sustainability of smallholder irrigation schemes in Zimbabwe. Journal of Biology, Agriculture and Healthcare, 4(15), 87-96.

Mutiro, J., \& Lautze, J. (2015). Irrigation in Southern Africa: success or failure? Irrigation and Drainage, 64(2), 180-192. https://doi.org/10.1002/ird.1892

Mwendera, E., \& Chilonda, P. (2013). Conceptual framework for revitalisation of small-scale irrigation schemes in Southern Africa: Revatalisation of small-scale irrigation schemes. Irrigation and Drainage, 62(2), 208-220. https://doi.org/10.1002/ird.1723.

Nangombe, S. S. (2014). Drought conditions and management strategies in Zimbabwe. Zimbabwe Meteorological Station. https://www.ais.unwater.org/ais/pluginfile.php/601/mod_page/content/29/Zimbabwe. pdf.

National Budget Statement. (2018). 'Towards a New Economic Order.' Government of Zimbabwe, Harare, Zimbabwe.

Ncube, A., Mangwaya, P. T., \& Ogundeji, A. A. (2018). Assessing vulnerability and coping capacities of rural women to drought: A case study of Zvishavane district, Zimbabwe. International Journal of Disaster Risk Reduction, 28, 69-79. https://doi.org/10.1016/j.ijdrr.2018.02.023

Nkambule, B. L., \& Dlamini, C. S. (2013). Towards sustainable smallholder irrigation development projects: A case study of the Maplotini irrigation scheme, Swaziland. Journal of Agricultural Extension and Rural Development, 5(10), 216-224.

Nyakudya, I. W., \& Stroosnijder, L. (2011). Water management options based on rainfall analysis for rainfed maise (Zea mays L.) production in Rushinga district, Zimbabwe. Agricultural Water Management, 98(10), 1649-1659. https://doi.org/10.1016/j.agwat.2011.06.002

Oriola, E. (2009). Breaking the vicious cycle in irrigation farming system for sustainable food security in Nigeria. African Research Review, 3(1), 234-245. https://doi.org/10.4314/afrrev.v3i1.43570.

The 2019 National Budget Statement. (2019). 'Austerity for Prosperity'. Government of Zimbabwe, Harare, Zimbabwe.

Transitional Stabilisation Programme Reforms Agenda. (2018). “Towards a Prosperous \& Empowered Upper Middle Income Society by 2030.” Government of Zimbabwe, Harare, Zimbabwe.

Ulsido, M. D., \& Alemu, E. (2014). Irrigation water management in small scale irrigation schemes: The case of the Ethiopian rift valley lake basin. Environmental Research, Engineering and Management, 67(1), 5-15. https://doi.org/10.5755/j01.erem.67.1.6240

Zawe, C. (2006). Reforms in turbulent times: A study on the theory and practice of three irrigation management policy reform models in Mashonaland, Zimbabwe.

Zimbabwe Agenda for Sustainable Socio-Economic Transformation (Zim Asset). (2013). "Towards an Empowered Society and a Growing Economy.” Government of Zimbabwe, Harare, Zimbabwe.

Zimbabwe Vulnerability Assessment Committee (ZIMVAC). (2012). 2012 Rural Livelihoods Assessment Report. Food and Nutrition Council, Harare, Zimbabwe.

Zimbabwe Vulnerability Assessment Committee (ZIMVAC). (2013). 2013 Rural Livelihoods Assessment Report. Food and Nutrition Council, Harare, Zimbabwe.

Zimbabwe Vulnerability Assessment Committee (ZIMVAC). (2014). 2014 Rural Livelihoods Assessment Report. Food and Nutrition Council, Harare, Zimbabwe.

Zimbabwe Vulnerability Assessment Committee (ZIMVAC). (2016). 2016 Rural Livelihoods Assessment Report. Food and Nutrition Council, Harare, Zimbabwe. 
Zimbabwe Vulnerability Assessment Committee (ZIMVAC). (2017). 2017 Rural Livelihoods Assessment Report. Food and Nutrition Council, Harare, Zimbabwe.

Publisher's Note Springer Nature remains neutral with regard to jurisdictional claims in published maps and institutional affiliations. 